\title{
ARTICLES
}

\author{
Henry Etzkowitz
}

\section{Beyond the Frontier: The Convergence of Military and Civilian R\&D in the U.S.}

\section{Introduction}

The end of the Cold war has inaugurated as significant a change in U.S. science and technology policy as brought about by the end of World War II. Just as a lack of land closed the frontier in the late nineteenth century, a lack of funds threatens its substitute, the so-called "endless frontier" of science (Bush, 1970). The scientific frontier, based on an inexhaustible supply of funds for military research, and militarily legitimated basic research, was similarly subject to closure in the late twentieth century. During the early post-war era a nominally independent defense R\&D sector emerged after a congressional struggle between scientists and the military over the control of nuclear research (Smith, 1965). A delicate political compromise created a system of scientist led weapons laboratories, managed by companies and universities under government contract (York, 1970; Kevles 1988). This scientific establishment was tied to the military but separated from civilian life even though it was officially under civilian control (Swomley, 1964; Nieburg, 1966; Melman, 1970; 1974).

The driving forces of current U.S. science policy are the contraction of the military economy and the need to make government supported research contribute more fully to the civilian economy in the context of increased international economic competition. The U.S. has had a dual economy since World War II, with a civilian economy which could, more or less (given the competition-suppressing activities of large oligopolistic corporations), be called a market economy, and a military economy which was essentially government controlled. Ideological prohibitions against breaching laissez faire walls between government and industry have required elaborate subterfuges to make direct intervention possible. During the Cold War, "national security" was invoked to support measures in such diverse areas as human resources and transportation policy, and state governments maintained their industrial policies on the 
grounds of traditional responsibilities for supporting local economies. The federal government, however, was expected to desist from such activities save for the exemptions granted by all-out war. It was only military and space competition with the former Soviet Union that provided exceptions to this ideology.

Three anomalies have appeared calling into question the "science policy paradigm" that has been in place since the end of the Second World War (Ruivo, 1994). The first anomaly can be found in Hans Skoie's observation that, "In Norway there is no reluctance for the government to intervene directly to support civilian technological development in comparison to the states where there is." (Skoie, 1994). However, see this statement may no longer be as true as it once was for the U.S. The logo of the Technology Reinvestment Program (TRP) (the two hands, one military, the other civilian, a circular linked chain going around them) represents the second anomaly (Cronberg, 1994), the emergence of a "decentralized corporatist planning system" in the operation of the TRP and other federally sponsored technology programs. The third anomaly is the maintenance of a high rate of military R\&D spending (Gummett, 1994) despite the lack of a technologically sophisticated opponent. Emerging convergences within and between military and civilian R\&D organizations is the key to explaining these anomalies.

\section{Disjunctures in the Military R\&D System}

After World War II the U.S. created a "dual linear system" for military R\&D with two starting points: military needs and fundamental investigation. Mission requirements originated within military strategic planning and were then translated into desired technical capabilities. Subsequent R\&D then mostly took place in the specialized industrial subsector that Seymour Melman called "Pentagon Capitalism," firms that were tied in to the military and primarily built weapons systems. Sometimes the requirements would come from the government and the firms would then conduct R\&D to realize the military's specifications. The firms could also put forth their own ideas for new weapons systems and then get seed funding to develop a concept or build a prototype.

However, the dual system created significant disjunctures between military and civilian innovation. When a firm conducted research the results had to be handed over to government so that the next step of development could be opened to competitive bidding. Naturally much of this competition was a facade and in reality the same firms usually continued on to build the systems they had initiated. Nevertheless, the requirement to turn over all results to the government led some firms to establish separate civilian and military R\&D divisions, with a wall between them, to protect their civilian proprietary R\&D from inadvertant disclosure. Alternatively firms concentrated solely on military R\&D. The disjunctures built into the system helped produce some of the super expensive equipment that has repeatedly been the object of congressional investigation. Such duplication was costly but not a problem for military innovation so long as civilian R\&D was less advanced.

The other linear system started from the opposite direction and moved from basic to applied research. Program officers in the Office of Naval Research (ONR), and the comparable offices in the other military services, had the discretion to fund what they judged to be the best leading edge research. The airforce, army and navy also had separate technology offices. Recently, the navy has combined its basic research and technology offices. The idea is, of course, to break down some of the barriers within the services. Links across the services are also increasing, through efforts to establish interagency committees. Formerly, such groups were largely formal devices. Given declining budgets or expectation of same there is more of a reality to the cooperative arrangements among the different research agencies, including combining related programs. Even if deep budget cuts should occur, R\&D 
program officers believe that the same level of R\&D can be continued cooperatively, by reducing extensive duplication.

The "dual linear" model of organizing $R \& D$ presumes a one way flow from basic to applied research, in one direction, and from mission requirements to technological capabilities, in the other. In the past, gaps in system have led to the creation of new bridging agencies. For example, in the aftermath of the crisis brought about by the Soviet Sputnik space achievement, an Advanced Research Projects Agency (ARPA) was created in the DOD in 1958 with broad responsibilities to pursue a wide range of far reaching projects spanning R\&D spectrum. The more recent Strategic Defense Initiative (SDI) project, founded in 1985, is an instance of a cross-cutting program within a particular R\&D field.

The gap within the defense R\&D system was further exacerbated by the widening gap between civilian and military technology. Civilian $R \& D$ has become more advanced especially in the electronics technologies which make up an ever increasing proportion of weapons systems (van Opstal, 1993). This reversal of an earlier trend in which defense procurement paved the way for civilian products was a sign of a maturing industry (Utterrback and Murray, 1977) Rapid technical advances on the civilian side of the industry were driven by large production runs, expanding markets, and new ideas for products. This brought about the unexpected phenomena of older technology embedded in weapons systems than could be found in local commercial electronics stores.

Segregation of research and production was reinforced as an unintended consequence of the "laissez faire" policies of the Reagan administration. During this era, the validity of government support for basic research at universities was accepted but there was a strong aversion to support of research in companies. Thus, government supported cooperative $R \& D$ projects among companies or academia and industry were avoided since the Reagan-Bush administrations thought industry an improper partner for government to support. A few exceptions were made under pressure from industry as the result of strongly felt need to meet Japanese competition in semi-conductors and micro-electronics.

Even as the executive branch widened the technology gap; Congress attempted to bridge it. Legislative initiatives to encourage closer linkages between universities and companies partially closed the technology gap, at least in principle. These links were mostly made downstream, after research had been completed, by turning over to universities the intellectual property rights to federally funded research conducted on campus and requiring academic institutions to make an effort to see that they were put to use. This indirect approach to industrial policy avoided some of the ideological objections to establishing direct links between government and industry outside of the defense sector (Etzkowitz, 1993).

\section{Reform Within the Military R\&D System}

For a brief period during and just after the Second World War, the military R\&D system was organized according to an ad-hoc spiral model with numerous feedback loops among research, development and production. Academic-industry collaboration was the norm in important efforts such as the "Radiation Lab" for the development of Radar, the Manhattan Project and the Distant Early Warning Line. This integrated model of R\&D was created by the academic scientists who organized the Office of Scientific Research and Development (OSRD) just before the Second World War. OSRD had broad responsibilities for $R \& D$ the early stages of production across the military services (Etzkowitz, 1993).

OSRD was disbanded immediately after the war and replaced by individual service R\&D (Offices of Naval, Army and Air Force Research) in the Department of Defense, established in 1947. A political struggle between advocates of military vs. civilian control of atomic energy resulted in the Man- 
hattan Project laboratories being moved from the control of the army to a new agency, the Atomic Energy Commission which eventually became the Department of Energy. The system of multiple $R \& D$ agencies in the Department of Defense and Department of Energy laboratories with similar missions encouraged competition but also resulted in duplication of effort and increased costs. The result was a loose confederation of the services, with only limited controls available to coordinate them. The considerable responsibility that had been given to OSRD was returned to the individual services after the war.

Since the Second World War, first, defense and then energy activities have been reorganized from special purpose mission agencies (e.g. Army and Atomic Energy Commission) into broad departments comprising their predecessor units. While the organization of R\&D has been affected by these bureaucratic revisions; it has also largely continued within the parameters defined by the original agencies. Problems in coordination and gaps in the mission agencies have been resolved by the creation of new subunits rather than through a drastic reconfiguring of the elements of these departments.

The R\&D organization of the Department of Energy, founded in 1977, is an amalgam of the nuclear weapons laboratories descended from the Manhattan Project and various energy research programs that it inherited from previously independent agencies such as the Bureau of Coal Research along with newer responsibilities for conservation and renewable energy. The DOE shares responsibility for development of nuclear weapons with DOD.

In the early 1960's, Robert McNamara, Secretary of Defense during the Kennedy and Johnson administrations, attempted to rationalize this system. Wishing to avoid a political battle that would have ensued if new legislation were sought to increase the influence of the Secretary of Defense, McNamara attempted to achieve the same goal through the imposition of information and planning systems, a measure well within his existing authority. He divided R\&D into discrete categories: 6.1 . basic and applied research; 6.2 exploratory development of the applications of that research and 6.3A, the construction of prototypes to demonstrate the principle of an application.

These categories were created in the belief that they would increase management control and improve efficiency; responsibility was then given to separate bureaus, in the different services, to administer programs in each category. Specific system development programs closely linked to procurement take place in categories $63 \mathrm{~B}$ and 6.4 . The former categories are said to represent "the tech base;" both sets comprise the "defense technology base" in DOD terminology (OTA, 1988:8). A portion of the technology base is nested in the "defense industrial base", comprising the companies that design and produce weapons as well as conduct $R \& D$ themselves.

The defence R\&D sector is in a state of flux today. Driven by severe budget constraints in the early 1990's, the military service $R \& D$ agencies are increasing their coordination to reduce duplication and share the support of projects and programs. According to a knowledgeable participant in the process, the former director of Livermore Laboratory, in a previous era: "We spent about twice as much money and employed about twice as many people on these development programs as we should have" (York, 1987: 102). At present, to eliminate waste informal coordination is being supplemented by formal planning mechanisms and some insiders think that merger of research, development and acquisition functions are a possibility in the future.

Rooted in a military culture; this system has been coordinated vertically, rather than horizontally - to the extent that coordination takes place. With the end of the Cold War the normative basis of this system is changing as military requirements are displaced by economic needs. Within the agencies themselves the integration of research and development activities is forced by "hard 
budget" constraints. Sharply reduced budgets make duplicative and disjunctive $R \& D$ policies, allowable in a period of rising budgets, impossible to sustain. Increased collaboration among research agencies, both military and civilian, is taking place as a result. A leaner defense R\&D system, more fully integrated into the civilian R\&D system will be the outcome.

Individual services, such as the Navy have already merged their science, technology and industrial relations units into a single organizational framework to insure closer collaboration. In some ways the restructuring of the military R\&D following the path of the reorganization of government supported civilian R\&D during the 1980's. Some of these same technology transfer mechanisms used by the universities are being taken up by federal laboratories. Dual university-industry and government-industry cooperative arrangements are being overlayed by broader arrangements for academic-industry-government collaboration (U.S. Congress, 1991).

Recent developments and current thinking at the Office of Naval Research provide an indicator of future directions. There is an atmosphere of change at ONR. Its director, Dr. Saalfield, believes that with end of the Cold War, "the world has turned again," requiring change potentially as significant as the establishment of the current system. He viewed the current shift as significant as the one that took place at the end of the Second World War. He holds that the current issue is, "... how to take a new step and integrate science and technology in a way that gets more out of funds; to replicate what was done in 1946 in a new way" (Saalfield, 1993).

The final barriers between the parallel $R \& D$ systems in the military and civilian economies are falling. Having merged its science and technology programs into a single unit, ONR also participates in joint committees with army and airforce research agencies to reduce duplication. The agency is seeking to establish ties with civilian research agencies such as NOAH. ONR plans to extend this outreach and "... bring indus- try more into play." The director said, "I'd like to form alliances with universities and industry [using] the agricultural extension services as a model for technical extension services." The goal is to infuse industry with new technology from ONR supported research, within the bounds of supporting science and technology to meet Navy needs. Nevertheless, in this new regime, given "... a choice between two programs of equal military merit; the one with commercial fallout would get support" (Ibid).

Since innovations currently take place primarily on the civilian side and can be taken over to the military side as needed; there is little basis for supporting a huge military research system for itself. If such a system is to be maintained on something approaching its present scale, it has to be justified on the basis of its contribution to civilian innovation. Certainly the capabilities are there. ONR program managers, for example, believe that their agency is more effective in supporting research than NSF, with its reliance on peer review, and some at NSF share this evaluation. ONR believes that government will want to use their demonstrated capabilities for new tasks. Indeed, the way that the TRP program has been organized, with military research funds providing the bulk of its support, is good evidence for the thesis of reorienting military research agencies in support of civilian goals, without removing them from the military context as occurred in Japan for reasons of political survival, just before the end of the Second World War. In the U.S. political exigencies suggest that it will be easier to support civilian research from within the military rather than risk an ideological controversy by attempting, for example, to civilianize ARPA.

\section{From Spinoff to Fraunhaufer Models}

In addition to defense contractors and university grant recipients, the military $R \& D$ system also includes the military's own labs and labs that companies and universities run for the defence and energy departments. 
Since the end of the Cold War the national laboratories have been revising their mission to include cooperative R\&D on civilian technology. There were three stages in the transformation or the labs into a support system for industrial R\&D. At first, in the 1960's, led by the National Aeronautical and Space Administration (NASA) the spinoff model was inaugurated, If a technology developed for a military purpose had a potential civilian application, then some funding was made available to support that transition. There has been much debate and many studies, from the 60's on, as to whether spinoffs are real or a mirage. Nevertheless, in 1986, Congress made technology transfer a subsidiary mission of the national laboratories, following by several years the assignment of such a mission to the universities. Funds were made available in the laboratory budgets for programs for cooperative research between national laboratories and firms. The cooperative research and development agreements (CRADA's) programs have grown greatly since they were established. Since the end of the Cold War, rather than it being a subsidiary mission, many of these laboratories have lost, or have significantly reduced their primary military mission. They have to find a new primary mission. The only one available is in the civilian economy or in the closest substitute they can find to military innovation, police equipment. There have been reports about laboratories trying to adapt military research to non-lethal police equipment. For example, Sandia labs has demonstrated a sticky substance that will help catch a criminal suspect but then there is the catch that the substance may trap the police officer, as well. There certainly is much room for skepticism as to whether this system of laboratories can be effectively transformed. But there is some lee way for the transition of the national laboratories.

The labs have such economic importance and thus political support in their local areas that there is very little political pressure just yet to look too closely at the transition effort or to consider closing some of them down. Nevertheless, just as there was a mil- itary base closing commission, which actually did close some military bases; there is the possibility that not too far down the road there will be a laboratory closing or restructuring commission. There will then be a review and at that point we will have some serious analysis of the extent which these laboratories have managed to transform themselves. What is clear now is they now that the old mission is gone. There are always a few people left who think that perhaps the Soviet Union will reappear; the old mission will come back.

However, most directors of national laboratories are quite realistic and know that they have to come up with a new mission tied to the civilian economy. Two obvious possibilities for a civilian mission for the laboratories are either spinning off "startup" firms or supporting existing firms in their $R \& D$ and product development. It can be expected that the national labs will increasingly justify themselves on local and national economic development grounds. As the laboratories are transformed into an R\&D support system for industry, the U.S. will acquire the virtual equivalent of the German Fraunhaufer Institute structure for its civilian economy

\section{Disjunctures in the Civilian Innovation Environment}

From the early post-war era through the 1960's, the prevalent innovation model was one in which a large firm, either in a traditional technology area such as chemicals (Monsanto) or in a newer one such as photocopying (Xerox) relocated its laboratories to a separate location from its production facilities, and then moved its headquarters to still another location. A disconnect between the different parts of the firm was introduced under the guise of functional specialization and modernization. During this period, despite predictions of a "triple revolution" based on automation, companies acted as if change would be relatively slow and that innovations could be phased in gradually to maximize profit. No matter what re- 
search came up with, the product line would be in place for a relatively long period of time.

Close connections among different parts of the company were considered to be less important than creating an attractive campus environment to attract scientists. A headquarters located nearby the CEO's place of residence could prevail over physical contiguity of the firms elements. Each component part of the firm could be located separately. Separation also allowed replication of elements, making possible the multi-national firm with manufacturing and $R \& D$ facilities located in different regions and continents (Fusfeld, 1994).

IBM was the quintessential distributed firm; with its world headquarters in suburban New York, Armonk, research laboratories in another part of Westchester, Yorktown and Hawthorn as well as Almaden California and Zurich Switzerland; development facilities in Boca Raton, Atlanta; the production facilities up in Fishkill, N.Y. Burlington, Vermont and elsewhere in the world. Under the strain of international competition, these disjunctures are breaking down both within large firms and between them.

On one hand, IBM has less resources to put into the basic research as an end in itself. For a long period of time IBM maintained its research laboratories, without expectating that they contribute to innovation within the firm, but as a national resource. Many of the technologies that were invented such as the reduced instruction set computing (RISC) weren't taken up by IBM for more than a decade. Many of these innovations were brought to market by other companies, typically startup firms that were spun out of universities with support from ARPA (for example SUN and Silicon Graphics workstation companies). During the Cold War defense department support for new firms, whose technology had long term military implications, was the actual industrial policy of the U.S. (Scott, 1993).

\section{Restructuring the Civilian Innovation Environment}

We are moving into a new innovation environment in the civilian economy. Individual companies, even the largest ones, no longer view themselves as self-sufficient. They increasingly rely on alliances with other firms, large and small, in their R\&D and product development (Harrison, 1994). Firms also look to universities as a source of technology as well as trained personnel. Local and regional government also view local universities in a new light as a potential source of contribution to the economy through the formation of start-up firms.

\section{Strategic Alliances}

Increasing international competition, requiring a quicker pace of innovation, has made strategic alliances among firms a common model for organizing innovation. Two or more firms or segments of large firms, come together and divide up an R\&D project, with each firm doing the part that it has special expertise in. This both speeds up the process and reduces the cost. Alliances have become a popular mode of operation and have spread quite broadly from R\&D to other aspects of corporate activity including purchasing and marketing. Now the concept is shifting again from discrete alliances for particular projects to longer term engagements. Firms that have come together for a single project might now develop a series of projects together in the same or related fields. This expansion of the concept suggests that alliances are evolving into a new innovation environment including large firms as well as start up firms who my have a particular area of technological expertise but not necessarily the development or marketing capabilities. Such firms would now tie in to these capabilities, without having to develop them themselves at an early stage this larger sector. Such ties often develop more fully among firms within the same geographical region (Saxenian, 1994, Etzkowitz, 1994a). 
Another recent development is the universities becoming more explicitly part of the innovation system as university-industry linkages spread across the academic system. Until 15 years ago, only a relatively few academic institutions such as MIT, Stanford, the land grant universities and a few engineering schools engaged in the transfer of technology to industry. In response to increased international competition and the decline of major sectors of U.S. President Carter, during the late 1970's, proposed to involve government more directly in reviving industry, through a policy of "reindustrialization." The political resistance in Congress to government taking such a direct role at the time was so strong that the executive branch abandoned the project, at least as an overt policy. This is the basis of what Hans Skoie referred to as the inability of the U.S. to have an industrial policy.

Nevertheless, in another guise, an industrial policy, going beyond reliance on military R\&D spinoffs was begun in 1980. At the initiation of Congress an indirect industrial policy was instituted in which the universities were used as a mechanism for government to reach industry. Government could not deal directly with the firms to encourage civilian innovation, this was ideologically forbidden territory, not only for President Carter who wished to, but certainly for Presidents Reagan and Bush who were firmly opposed to such an interventionist policy.

However on another related issue, both proponents and opponents of industrial policy could agree that the enormous amount of potential intellectual property that had accumulated in the universities, arising from federal research grants, should be privatized. Research results with potential commercial utility were in an uncertain legal status as to who really owned them. Officially, of course the federal government owned these rights. Given the strength of anti-industrial policy feeling the federal government was hardly going to engage in R\&D or commercialization activities and firms were not willing to undertake these tasks in the absence of a clear title. If they did produce something suc- cessful, another firm could come along and say: why this technology originated from a government sponsored research project, we have an equal right to it as taxpayers and citizens; hand it over. For this reason, such government owned intellectual property tended not to be utilized.

The outcome of the late 70's debate over whether to have a federal civilian industrial policy was that nothing was done directly. Nevertheless a hidden industrial policy and programs to carry it out were was set in motion indirectly. It was seemingly established for another purpose to clarify the ambiguities in federal intellectual property rights by turning them over to the universities but with a condition. The proviso was that universities had to take steps to commercialize this intellectual property. From 1980, the general research university system of academic institutions managing significant federal research grants started administrative offices and began to experiment with various models of technology transfer and relations with industry. Most of these formats for academic-industry relations had been developed over the past 60 or 70 years at MIT and then were taken up at Stanford after the Second World War. These practices were generalized throughout the research university system as an outcome of the failed debate on industrial policy.

Thus, schools such as MIT and Stanford which had been anomalies within the U.S. academic system now became the models for other universities to emulate. Schools such as Columbia which previously viewed themselves as playing a policy and service role in having faculty members go to Washington to serve temporarily in government now found themselves trying to establish new ties with industry, often in their local region. They typically did this by assigning the task to an attorney who was already a member of the administrative staff or by hiring a scientist from industry as Director of Technology Transfer.

The academic technology transfer office would then focus on areas of research with commercial possibilities, identifying poten- 
tial intellectual property for patenting and licensing and making contacts for their sale to industry. Soon, intermediary groups appeared and organized regular meetings and conferences to bring university technology transfer offices together with industry scouts to facilitate the transfer process (Etzkowitz, 1993). Within 15 years, technology transfer activities became a significant moneymaker for a few universities that originated significant technologies. Others are still gearing up their offices or waiting for technologies to receive health and safety approvals, so that the royalty flow to the university and its faculty can begin.

The actual and potential financial worth of academic technology transfer has recently received unfavorable public attention in the media and in Congress as the result of publicity about foreign corporations utilizing the new technology transfer procedures to gain access to U.S. technology. The intent of Congress in indirectly encouraging the establishment of an academic technology transfer capacity was to improve the competitiveness of U.S. industry. Some congress persons were distressed to learn that these very mechanisms were being taken advantage of by overseas competitors. Moreover, some technology transfer deals have been for costly drug products, raising the issue that public funds which paid for the research were producing inflated profits for companies at the expense of the public that had originally funded the research through its tax dollars.

A sufficient issue emerged that some members of Congress have called for the federal government to take hack some of the intellectual property rights that it gave away in 1980. The feeling was expresses that the universities were earning too much money and that some of these profits should be used to lower drug prices instead. By the time this threat to university technology transfer had developed, the academic technology transfer profession had developed to a sufficient extent that it had its own professional association, the Association of University Technology Managers (AUTM) with a regular schedule of national and regional conference and training programs for prospective technology transfer officers as well as special media such as the Technology Access Report Newsletter.

In response to the growing controversy AUTM organized a Congressional hearing, through its own supporters in Congress, demonstrating that the original intent of the legislation establishing academic technology transfer was to gain national benefit from the long term outcomes of technology transfer. Therefore, these processes of technology transfer in the universities should be left alone. The return to government would come from increased taxes in the future and government should not try to interfere and possibly short circuit the process. The political pressure that emerged and then receded in the face of a successful counterattack from the academic technology transfer interest group that has emerged in support of the legal basis on which the profession rests suggests that this mode of innovation has become institutionalized (MacNiece, 1994).

\section{The Convergence of Military and Civilian R\&D}

The thesis of "dual use" technology has been propounded in an attempt to resolve the inefficiencies of a bifurcated $R \& D$ system (Branscomb, 1993). Its proponents suggest using defense $R \& D$ resources to stimulate civilian technologies on the grounds that they can be simultaneously used by the military and transferred into the civilian economy. A clear military use is still a requirement of the dual use R\&D strategy; it stops short of industrial $R \& D$ policy, that is, openly providing government support for advance of purely civilian technologies.

An expanded role has been proposed for ARPA in industrial development. A report commissioned by the Carnegie Commission on Science, technology and government, a private group comprising distinguished scientists, community leaders and former government officials contains a variety of prescriptions for improving U.S. economic per- 
formance. The most controversial proposal concerns the interplay between military and commercial R\&D. Resting on the assumption that the U.S. has two technology bases (a defense technology base and a commercial technology base) the Commission recommends that ARPA, which funds research into advanced technology with potential military applications, be transformed into the National Research Projects Agency (NARPA) The renamed agency would step beyond its existing mission to fund research on advanced civilian technologies with military implications at the request of other agencies than the defense department. Thus, ARPA or NARPA would become a government wide agency in its ability to undertake tasks for non-military departments but would still be restricted in its actions by the requirement that these tasks have military implications.

The Carnegie Commission's ARPA proposal falls within the framework of the socalled concept of "dual-use" technologies. A dual use technology as the name implies is one that can be used for both military and civilian purposes. It is a half-way house between avowedly military and clearly civilian technologies. While it is a concept that can be stretched to incorporate many technologies with civilian implications, for example, media for training programs applicable both to the armed services and k-12 education, the focus is still on the military uses of technology. Indeed, according to Lewis Branscomb (professor at Harvard University's Kennedy School of Public Policy former IBM technology chief) the suggestion for a ARPA to NARPA transformation has much more to do with assuring that the defense departments has access to the best technology, whatever its source, than to using the agency to improve U.S. economic competitiveness. It is believed that through partnerships in developing dual use technologies that defense has the best chance to gain access to leading edge commercial technologies as they are created rather than after they are manufactured. The reorganization of defense $R \& D$ is part of a broader shift in U.S. industrial policy.
During the Bush administration, Craig Fields, then a DARPA official, attempted to broaden the definition of national security to include economic security. Under this umbrella, he planned to support RD in civilian technologies that were an underpinning for military technologies. This approach was rejected at the time by the administration as representing an unacceptable venture into "industrial policy" which the Bush administration viewed as an impermissible and misguided attempt on the part of government to "pick winners and losers" in the civilian economy. Fields soon left DARPA to become head of MCC, a government supported corporation designed to do for a sector of U.S. industry what he had just been forbidden to institute for a broader range of industries.

This event illustrates the episodic and often contradictory thrust of U.S. science and technology policy in the recent past. It moved in fits and starts, in part because it could only be accomplished as an upstream movement against a strong tide of resistance from believers in a laissez faire ideology of governmental non-intervention in the economy. Nevertheless, even the strongest adherents of this set of beliefs will stand aside if there are strong pragmatic reasons for doing so. For example, under pressure from the semiconductor industry, the Reagan administration agreed to use government funds to support the creation of SEMATECH, a government-industry research program to speed innovation in that industry.

SEMATECH, the consortia of semi-conductor manufacturers, founded in 1987 with DOD and industry funding, is currently viewed as a model for other industries (Hafner, 1993). Although supported by government, the consortia is led by its industry members. An analysis of the industry's competitive problems with Japan revealed deficiencies in manufacturing; these were to be remedied by, among other means, establishment of an engineering research center staffed by researchers drawn from individual member companies. SEMATECH's research facility was located in close proximity to the University of Texas, Austin. An im- 
portant reason for choosing this location was a commitment by the state of Texas to expand university research in this field, thereby making a larger group of academic researchers available to collaborate with their counterparts at SEMATECH. In this model, DOD is a largely silent partner, with academia a subsidiary element, of an industry led pre-competitive R\&D scheme. SEMATECH has recently announced that it will no longer need government funds; henceforth it will be based so on industry support.

\section{The Emergence of a "Planning System" in the U.S.}

The impetus for convergence between the military and civilian spheres is largely an outgrowth of the end of the Cold War. The demise of military competition between the U.S. and the former USSR brings to the fore the issue of military R\&D budgets (Gummett, 1994) The third anomaly is the continuing high level of expenditures on research in contrast to the reductions in procurement of new military hardware. Does the high level of expenditure on research in the U.S. arise from an uncertain military environment in which we cant be certain what is the next threat and thus have to lay a wide range of bets. To follow up Hans Skoie's point about the inability of the U.S. government to pursue a civilian technology innovation policy: the military R\&D budget is currently being used as a resource to fund civilian innovation indirectly. Government support for civilian technology development is not taking place in the quise of a weapons program as many in Europe feared was the case with Star Wars. Rather the military R\&D budget is increasingly being utilized for civilian ends. A credible military R\&D threat to the U.S. no longer exists. No one has been able to reinvent the Soviet Union. Perhaps in the Nordic countries there is still concern about reversion to the past but scenarios for a revived arms race receive little elsewhere. Some have tried to substitute the North Koreans for the Soviets but even their bellicosity appears amenable to solution. In any event a potential conflict with North Korea, or with any other conceivable adversary, hardly requires an R\&D effort on the scale of the race between the U.S. and the former Soviet Union.

Defense policy continues to be based on the assessment that the U.S. might have to fight two regional wars at the same time. Even at that level of extensive use of force, given the type of conflicts expected and capabilities of the prospective opponent there is little justification for R\&D expenditures at Cold War levels. Nor is there any country on the horizon, with the sophisticated scientific and technical resources and capabilities of the former Soviet Union, that will conceivably engage in a military $R \& D$ race with the U.S. Nevertheless, since high research budgets persist we must then ask: what is happening within these budgets. Let us open up the black box of the TRP and see what is going on inside.

The TRP brings together experts and resources from different parts of government to support technological innovation in industry but the bulk of the funds come from the military budget. The TRP is led by the Advanced Research Projects Agency (ARPA), the defence $R \& D$ agency that focuses on generic technology. ARPA was formed after the Sputnik crisis in 1957 to engage in broader, more long range technology development and research infrastructure projects, filling the interstices in between the separate navy, army and air force $R \& D$ programs. The TRP is devoted to defense conversion; another program in NIST The Advanced Technology (ATP) is directed at civilian technology more generally. The scale of resources required to compete for funds in these programs makes them accessible primarily to larger firms. The Small Business Innovation Research Program (SBIR), a "tax" on research agency funds, (currently $2 \%$ ) operates through a similar format.

How do the ATP, TRP and SBIR spend their funds? Although there is an open call for proposals in any relevant area of commercializable science and technology, these 
programs increasingly rely on a more focused approach based upon the critical technologies list. Such lists are hardly unique; virtually the same broad topics can be found on lists in the U.S. Japan in Europe. Nevertheless, within the broad guidelines of the list, government R\&D program managers and companies suggest specific aspect of technologies for special attention. Once the program agrees that a proposed technology is deserving of special attention a conference call is issued. The conference brings together TRP program managers with representatives from companies, both large and small, that are interested in working on the technology. Academics also attend; they can not initiate a proposal but can participate in these programs as members of company led consortia.

The meetings are held in workshop settings in which the discussion focuses on the area of blockage that needs to be addressed to move the particular technology forward. Once a consensus is reached the next step is that the program conducts a competition for the funds in which both technical and business reviews are carried out. In the ATP and TRP programs companies also have to commit matching funds. Through this process government involves itself directly in support of civilian R\&D in addition to influencing industry indirectly through the university technology transfer programs that the federal government encouraged by transferring the intellectual property rights deriving from federal research grants to the universities.

These technology blockage brainstorming sessions, attended by government, industry and academic representatives, and the decision that results to mount a competition for funds in the area of blockage identified, constitute an informal, corporatist, bottom up planning system. Planning is done jointly by the government side, by the industry side, with both large and small companies participating as well as academics. Out of these discussions, the Request for Proposals (RFP'S) are made much more specific. Instead of being directed toward a general crit- ical technology which is typically so broad a category as be almost meaningless for targeting innovation, the planning process reduces the general category to a particular point, at which the people who are closest to the technology agree, that a blockage exists.

Industry, government and academia together target what the historian Thomas $P$. Hughes (1983) has called "reverse salients," technical problems which, if successfully addressed, open up new technological and economic vistas; eventually creating new companies, industries and jobs.

Congress began the ATP and TRP programs on a very small scale during the Bush administration; SBIR is an even earlier initiative. The new element in the Clinton administration is that the ATP and TRP have been scaled up dramatically. A quantitative shift in funding is creating a qualitative change in government policy. What was a 20 million program in the previous administration is now a quarter of a billion and is moving very rapidly to 3 quarters of a billion within a few years (Good, 1994).

A major structural and ideological change in U.S. science and technology policy is underway even though no new laws have been passed. The Clinton administration has not put forward a legislative proposal for civilian innovation comparable to the ill fated health care initiative. Nevertheless, a shift in funds and a transformation of program management procedures is bringing about a new relationship among government, industry and academia. The discussion processes built into the ATP, TRP and SBIR are creating a corporatist environment in which sectors that formerly acted separately are working together. To get access to funds from the TRP or ATP it is often necessary to create a consortia of large and small firms with complementary $R \& D$ skills, with perhaps a university research center brought in to assist with the basic end of the project. Thus, the model of strategic alliances is being extended from industry to academic-industry relations and from the civilian into the military environment and across the two. The handshake 
in the TRP logo represents this latter conjunction of interests.

The reorganization of military $R \& D$ is part of a broader shift in U.S. industrial policy. A federal laboratory system dedicated to weapons development is being redirected to support of industrial activity. This follows an earlier shift of the universities toward industrial support in the 1980's. Now both sectors of public sector research - universities and government laboratories - have been reoriented toward the same goal. The strategy is to revive a declining civilian industrial economy by connecting it more tightly to research capacities, initially in the universities in the early 1980's and then to federal laboratories later in the decade. The innovation environment currently being created in the U.S. combines elements of a planning system with elements of a corporatist system at the federal level; it also includes the various state programs that grew up during the 1980's when the federal government removed itself from supporting near market technological development. The federal government currently supplies money to the states to expand their outreach programs to improve manufacturing in firms. At the local level innovation systems are emerging based upon strategic alliances connecting companies and the national laboratories, drawing upon industry, state and federal funds for joint projects. Following Japan and Western Europe, the U.S. is developing a national innovation policy from these programs and alliances.

\section{Corporatism American Style}

Corporatism, the European doctrine of cooperation among government, industry and labor, is being Americanized (Streeck, 1993). American corporatism is characterized by the emergence of an interventionist state, in science and technology policy, at the federal and state levels. Government plays an increasingly open role in setting industrial policy in cooperation with industry and academia. American corporatism is devel- oping within the technology programs originated during the Bush administration at the instance of Congress and greatly expanded by the Clinton administration. The ATP and TRP programs have developed a bottom up planning system, bringing together representatives of government agencies, firms and academics to identify technological blockages to be addressed by government supported consortia of industry and university researchers. Paid for largely by funds from military R\&D programs, the new civilian $R \& D$ programs are expected to enhance a common civilian and military industrial technology base.

Until the Clinton Administration only a "hidden" industrial policy was politically acceptable at the national level (Etzkowitz, 1991). Ideological prohibitions against breaching "laissez faire" walls between government and industry required elaborate subterfuge to make intervention possible. During the Cold War national security was invoked to support measures in such diverse areas as human resources and transportation policy. Under this common rubric a graduate school fellowship program and an interstate highway construction program were both instituted during the 1950's. State governments maintained their industrial policies on the grounds of traditional responsibilities for supporting local economies (Eisinger, 1988; Graham, 1992; Dougherty and Etzkowitz, 1993). The federal government, after the abortive attempt of the National Industrial Recovery Act (NIRA) programs of the 1930's depression, was expected to desist from such activities save for the exemption granted by all-out war.

Lacking ideological blinders the current administration is actively seeking to implement an industrial policy. Unable to obtain new resources from Congress, it is attempting to redirect existing resources to support its goals of job creation, formation of new firms and reviving the technologies of existing firms. Not since the Japanese agency responsible for military $R \& D$ moved itself from the War department to the Commerce department in the closing days of the sec- 
ond World War, recreating itself as MITI (Johnson, 1982; Patrick, 1986), has such an important transition been at hand. The U.S. Departments of Defense and Energy are restructuring themselves and their relationships with industry and universities. As they expand their mission from contracting for R\&D to supporting technology transfer; they are carving out a new role for themselves in U.S. industrial policy during the post Cold War era.

\section{Conclusion: U.S. Industrial Policy: Coming or Going?}

The 1994 mid-term election results appear to presage a gloomy future, and brief past, for activist science, technology and industrial policy. During the Reagan and Bush administrations, conservative academics and politicians enforced a hands-off approach to civilian industrial policy, preferring to rely on (mythical) free markets and government intervention through the military economy. Throughout the rest of the world, governments and groups of companies joined together to gain a competitive edge. In the U.S., only the strongest lobbying efforts of a united semiconductor industry (with the support of the military) were able to overcome ideology to create Sematech. More quietly, lifting the (liberal) threat of anti-trust litigation sparked the creation of hundreds of research consortia during the 1980s.

While critics still question Sematech's role in the revival of the U.S. semiconductor industry (Noll and Cohen, 1994), skeptical pragmatists still may properly ask, can the U.S. government play a legitimate role in fostering industrial competitiveness; do federal agencies have the intelligence and capabilities to accomplish this purpose? The optimistic answer lies in the innovative approach that the administration has taken to organizing the ATP, TRP and SBIR programs, encouraging participation by firms large and small, local and state governments and academia.

The Clinton administration's decentralized planning system for identifying and overcoming technical barriers has created a series of industry-government and academic R\&D consortia in both old industries e.g. lasers for customized clothing design and emerging industries e.g. new thin film processes for photovoltaics production. The conferences held across the country, bring together representatives from industry, academia and government, to discuss problems in specific technologies constitute a new form of bottom-up R\&D planning within a stage set provided by the federal government. These efforts promise to reduce duplication of effort and bring academic, corporate and governmental skills to bear on R\&D bottlenecks in a concentrated fashion. Such programs, even in a lower key civilian format, have not been seen in the U.S. since the Office of Scientific Research and Development (OSRD) efforts of the Second World War on radar, the proximity fuse and the atomic bomb.

OSRD, of course, was disbanded immediately after the close of hostilities; it must now be ask will the Clinton administrations innovative approach to civilian R\&D be abandoned before they have a chance to bear fruit? Have these new programs created sufficient constituencies who find them worthwhile, and can demonstrate their worth, against attacks upon corporate welfare? Some Republicans wish to return to a military-dominated economy. With the end of the Cold War and the lack of any credible technologically advanced opponent; such expenditures would be a sad, wasteful and exceedingly indirect way of subsidizing targeted industries. In the 1930s a Democratic president saved business against its own protestations; in the 1990s it is one of the ironies of the current political situation that a president who has done more for business than any recent president has failed to keep the support of business.

It is in the country's interest to move industry forward, cooperatively as well as competitively, in its R\&D and product development. In the coming months we shall learn whether this principle, long accepted in the 
U.S. military economy, is to be allowed to flourish in our civilian economy, as well. The Clinton administration's approach to industrial policy does not attempt to "pick winners," nor is it "industrial welfare," as Labor Secretary Reich has characterized an older style of industrial and social welfare policy such as preferential tax cuts. It may be relevant to compare "workfare" to industrial policy in that both presume an active effort on the part of participants rather than receipt of funds as a matter of right.

Some academics say they prefer to return to the old days before extensive federal research funding was available, arguing that with less resources the universities will better be able to concentrate on their "core" tasks of basic research and teaching. Similarly, many people in the technology transfer community say they preferred the old days of minuscule resources and no public awareness to the current state of merely inadequate resources, soaring expectations and intense public scrutiny. Those days are gone. The Clinton administration's knowledge-based industrial policy is technology transfer writ large and with an open, bold face; no longer hidden behind a research agenda as an afterthought.

In his letter of charge to OSRD toward the end of World War II, President Roosevelt praised the scientific community for successfully applying its skills to the prosecution of the war effort. He called upon the leaders of that community assembled in a committee to consider the future of government support for $R \& D$ and asked them to devise a scientific and technological effort commensurate with the need to solve imminent peacetime problems of housing and employment. For more than four decades Roosevelt's plea for peacetime R\&D was submerged under the Cold War competition with the former Soviet Union. His call for what we now call "strategic" civilian research has been misinterpreted as a legitimation for fundamental research conducted in an isolated fashion. The scientific and technological community is now at a turning point: it can attempt to recreate the recent past and sup- port retention of a militarily based industrial policy (the Republicans offer that opening) or it can take a step into the future and attempt to realize Roosevelt's vision of a government supported civilian $R \& D$ policy that his OSRD committee failed to specify at the time.

During the past two years, the Clinton administration, both through its own experimentation and adaptation of ARPA models for military R\&D planning, has created the outlines of such a policy and launched dozens of exemplars for its realization. The scientific and technological community is no longer an isolated powerless, entity, requiring special protection behind special boundaries. Through criticism and opposition, many of its members helped bring about the end of the Vietnam War and a close to nuclear testing. Most members of scientific and technological community, especially an older generation of academics grounded in an expectation of a succession of renewed research grants, currently uphold the banner of a legitimate role for government solely in support of basic and military research, a throwback to the "Endless Frontier" (Etzkowitz, 1993) Some members of a younger generation of academics uncertain of their academic survival in a constricted grants economy and a few academic and industrial scientists who see synergies in simultaneously pursuing theoretical and practical research questions, are open to new modes of research support in which technology transfer is integral to formulation of the research agenda (Etzkowitz, 1994; Good, 1994). Will industrial sectors that are receiving $R \& D$ and product development support form the administrations's programs attest to their validity? Will related concepts of autonomous markets and scientific autonomy override material conditions of the necessity for government, corporate and academic institutions to cooperate more closely in an area of increased economic competition in which the U.S. is not the taken for granted leader as it was during the early post-war era. In addition to a another test of the comparable worth of the "Marxian" and "Weberian" theses of 
the relative weight to be assigned to ideational and material factors in social change; the institutionalization or demise of the Clinton Administration's nascent industrial policies will be affected by the outcome of this debate over the future of science policy.

\section{REFERENCES}

Air Force

1993 "The Air Force Technology Transfer Program" unpublished manuscript.

Branscomb, L

1993 Empowering Technology: Implementing a US Strategy Cambridge: MIT Press.

Bush, $V$.

1970 Pieces of the Action New York: Morrow.

Carnegie Commission on Science, Technology and Government.

1992 A Science and Technology Agenda for the Nation: Recommendations for the President and Congress New York: The Carnegie Commission.

Center for Strategic International Studies

1993 Roadmap for MILSPEC Reform: Integrating Civilian and Military Manufacturing Washington D.C.: Center for Strategic International Studies.

Congressional Budget Office

1990 Using RD Consortia for Commercial Innovation: SEMATECH, X-ray Lithography and High-Resolution Systems Washington D.C: U.S. Government Printing Office.

Congressional Budget Office

1993 Promoting High-Performance Computing and Communications Washington D.C: U.S. Government Printing Office.

Cronberg, $\mathrm{E}$

1994 "Presentation at NATO Defense Conversion Workshop" Budapest, Sept.

Department of Energy

1982 An Assessment of the Basic Energy Sciences Program" Office of Energy Research, Office of Program Analysis.

Department of Energy

1985 "Industrial Application of Intense Pulsed Neutron Source" Argonne National Laboratory.

Dougherty, K. and Etzkowitz, $\mathrm{H}$.

1993 "The States and Science: Industrial Policy at the State Level" American Sociological Association Annual Meetings, August.
Eisinger, $P$.

1988 The Rise of the Entrepreneurial State: State and Local Economic Development Policy in the United States Madison: University of Wisconsin Press.

Etzkowitz, $\mathrm{H}$

1991a "Regional Industrial and Science Policy in the United States" Science and Technology Policy April 4(2): 10-15.

Etzkowitz, $\mathrm{H}$.

1993b "The National Science Foundation and United States Industrial and Science Policy" Science and Technology Policy Feb. 6(1): 10-15.

Etzkowitz, $\mathrm{H}$

1993c "Technology Transfer: The Second Academic Revolution" Technology Access Report, June.

Etzkowitz, $\mathrm{H}$.

1993d Interview with Dr. Robinson, Office of Naval Research, July 122.

Etzkowitz, $\mathrm{H}$.

1993 e Interview with Dr. Saalfield, Director, Office of Naval Research, July 22.

Etzkowitz, $\mathrm{H}$.

1993f Interview with Irwin Pikus and Deborah van Opstal, The Center for Strategic and International Studies, July.

Etzkowitz, $\mathrm{H}$.

1993g Interview with Lewis Meixler, Director of Technology Transfer, Princeton Plasma Physics Laboratory, June.

Etzkowitz, $\mathrm{H}$.

1993h Interview with Dr. Culpepper, Office of Naval Research, July 22.

Etzkowitz, $\mathrm{H}$.

1993i Interviews at Office of Procurement, Office of Technology Utilization and Office of Science Education and Technical Information, Department of Energy, June.

Etzkowitz, $\mathrm{H}$.

1993j Interview with Lee Rivers, Director, The National Technology Transfer Center, June.

Etzkowitz, $\mathrm{H}$.

1993k Telephone interview with Jorgen Birkeland, Office of Fossil Fuels, DOE, November 4.

Etzkowitz, $\mathrm{H}$.

1993I Telephone interview with Paul Christian sen, Administrator, Center for Telecommunications Research, Columbia University, Nov.

Etzkowitz, $\mathrm{H}$.

1993m Telephone interview with Duane Adams, Advanced Research Project Agency, DOD. Nov.

Etzkowitz, $\mathrm{H}$.

1994 "Technology Centres and Industrial Policy: The Emergence of the Interventionist State" Science and Public Policy, February 
Good, M.

1994 "Address to New York State Biotechnology Association" Oct.

Graham, $\mathrm{O}$.

1992 Losing Ground: The Industrial Policy Debate Cambridge: Harvard University Press

Gummett, P. \& Edith C.

1994 "Presentation at NATO Defense Conversion Workshop" Budapest, Sept.

Hafner, $\mathrm{K}$.

1993 "Does Industrial Policy Work? Lessons from Sematech" New York Times, Sunday, November 7 F 5 .

Harrison, B.

1994 Lean and mean: The Changing landscape of Corporate Power" New York: Basic Books.

Hughes, T.

1983 Networks of Power: Electrification in Western Society, 1890-1930. Baltimore, Johns Hopkins University Press.

Johnson, C.

$1982 \mathrm{MITI}$ and the Japanese Miracle: The Growth of Industrial Policy, 1925- 1975. Stanford: Stanford University Press.

Kevles, D.

1987 "RD and the Arms Race: An Analytical Look" In Mendelsohn, Everett and M.R. Smith and Peter Weingart. 1988. eds. Science and the Military. Dordrecht: Reidel.

Kostoff, R.N.

1988 "Evaluation of Proposed and Existing Accelerated Research Programs of the Office of Naval Research" IEEE Transactions on Engineering Management. Nov. 35: 271-279.

Kundert, $T$

1993 "Air Force Implementation of Cooperative Research and Development Agreements (CRADA's) Under the Federal Technology Transfer Act " Air Force Legal Services Agency.

Mansfield, E.

1991 "Academic Research and Industrial Innovation" Research Policy. 20(1): 1-12.

McCartney, S.

1993 Los Alamos Lab Seeks to Speed Tech Transfers" Wall Street Journal

1970 Pentagon Capitalism. New York: McGraw Hill.

Melman, $\mathrm{S}$.

1974 The Permanent War Economy. New York: Simon and Schuster.

Mullins, $\mathrm{N}$.

1983 "Argonne National Laboratory: Social Analysis of a Research Organization" unpublished manuscript

National Science Foundation

1993 Selected data on Federal Funds for Research and
Development: Fiscal Years 1991, 1992, and 1993 National Science Foundation, Science and Engineering Activities Program, Division of Science Resource Studies

Nelkin, D.

1972 The University and Military Research: Moral Politics at MIT Ithaca: Cornell University Press.

Nelson, R., Merton P. and Kalachek R.

1967 Technology, Economic Growth and Public Policy Washington D.C.: The Brookings Institution.

Nichols, $R$.

1985 Testimony presented before the U.S. House of Representatives, Committee in Science and Technology, Task Force on Science Policy, Oct. 13.

Nieburg

1966 In the Name of Science New York: Quadrangle Press.

Office of Technology Assessment

1986 Research Funding as Investment: Can We Measure the Returns? Washington D.C: U.S. Government Printing Office.

Office of Technology Assessment

1988 The Defense Technology Base: Introduction and Overview Washington D.C: U.S. Government Printing Office

Office of Technology Assessment

1989 Holding the Edge: Maintaining the Defense Technology Edge Washington D.C.: U.S. Government Printing Office

Office of Technology Assessment

1991 Federally Funded Research: Decisions for a Decade] Washington D.C: U.S. Government Printing Office

Patrick, $\mathrm{H}$.

1986 Japan's High Technology Industries: Lessons and Limitations of Industrial Policy Seattle: University of Washington Press

Ruivo, B.

1994 "Paradigm for Science Policy" Science and Public Policy.

Saxenian, A.

1990 "Regional Networks and the Resurgence of Silicon Valley" California Management Review, Fall.

Scott, A

1988 New Industrial Spaces London: Pion.

Smith, A. K.

1965 A Peril and a Hope; The Scientists Movement in America, 194 5-1947 Cambridge: MIT Press.

Soderstrom, J. and Winchell B

1986 "Patent Policy Changes Stimulating Commercial Applications of federal RD" Research Management, May-June: 35-38. 
Swomley, J.

1964 The Military Establishment Boston: Beacon Press.

Technology Access Report

1993 "Energy Department's Week of News" July 30, 1993.

Technology Access Report

1993 "MCC Ventures, Inc. to Take Over Some Los Alamos Tech Transfer" Technology Access Report Vol.6. No.9 September.

\section{U.S. Congress}

1975 Hearings Before the Subcommittee on Small Business, U.S. Senate. 94th Congress. Energy Research and the Development of Small Business.

U.S. Congress

1976 Hearings Before the Subcommittee on Monopolies and Commercial Law, Judiciary Committee 94th Congress, First and Second Sessions on Energy. Serial No. 48.

\section{U.S. Congress}

1991 Department of Energy Science and Technology Partnership Act. 102nd Congress.

van Opstal, D.

1993 Integrating Civilian and Military Technologies: An Industry Survey Washington D.C.:Center for Strategic International Studies.
Utterback, J. and Murray A.

1977 The Influence of Defense Procurement and Sponsorship of Research and Development on the Development of the Civilian Electronics Industry Cambridge: MIT Center for Policy Alternatives.

Vietor, R.

1984 Energy Policy in America Since 1945: A Study in Business-Government Relations Cambridge: Cambridge University Press.

Weingarten, $\mathrm{F}$.

1993 "HPCC Research Questioned" Communications of the ACM, November Vol. 36 No. 11: 27-29.

York, $\mathrm{H}$.

1970 Race to Oblivion: A Participants View of the Arms Race. New York: Simon and Schuster.

Henry Etzkowitz

Computer Science

Columbia University

New York 10027

USA 